\title{
Untreated Childhood Pilomyxoid Astrocytoma
}

National Cancer Institute

\section{Source}

National Cancer Institute. Untreated Childhood Pilomyxoid Astrocytoma. NCI Thesaurus.

Code C115952.

A finding of pilomyxoid astrocytoma in childhood that has not been treated. 